\title{
PENGEMBANGAN PRODUK OLAHAN JAGUNG MELALUI UJI KESUKAAN KONSUMEN
}

\author{
Rika Diananing Putri ${ }^{1}$, R. Amilia Destryana ${ }^{2}$ \\ ${ }^{1,2}$ Staf Pengajar Prodi Teknologi Hasil Pertanian,Fakultas Pertanian Universitas Wiraraja \\ email: rikadepe@wiraraja.ac.id
}

\begin{abstract}
This study aims to develop corn processed into a product that is beneficial to the health of the body and to determine consumer preferences for functional drinks, namely corn yogurt. Functional food needs to get attention so that its use has the correct scientific evidence basis, claims are not misleading and do not encourage wrong consumption patterns. One of the development of processed corn is functional food products such as yogurt. In order to be accepted by consumers, a test of preference for color, texture, aroma and taste was carried out by adding 10\%, 12\% and 14\% fullcream milk. Conclusions produced by the community / consumers prefer yogurt with the addition of $12 \%$ fullcream to color, texture and aroma, while for consumers' taste like the addition of fullcream at $14 \%$. This is due to the addition of $14 \%$ sour and sweet taste fullcream is felt.
\end{abstract}

Kata Kunci: Yoghurt, Functional food, preferences

\section{PENDAHULUAN}

Pengembangan merupakan salah satu cara untuk meningkatkan jagung menjadi produk yang dapat bernilai jual tinggi yaitu dengan mengubah atau memberikan sentuhan teknologi sehingga memberikan manfaat bagi konsumen. Teknologi yang diberikan yaitu membuat nilai jagung menjadi pangan yang memberikan manfaat bagi kesehatan.

Produk olahan berbahan dasar jagung manis sudah banyak diproduksi seperti kue basah dan tojin, susu jagung, bubur jagung, congurt, yogurt, conflake dan lain-lain. Jagung manis diolah menjadi pangan fungsional seperti yogurt, (Amelia, n.d.) menjelaskan inovasi produk berupa yogurt salah satu alternatif dalam menyediakan pangan fungsional yang lebih terjangkau. (Anggono;dkk, 2017) menjelaskan bahwa kandungan susu jagung (Zea mays L Saccharata) adalah karbohidrat dan lemak.
Strategi pengembangan jagung (Aldillah, 2017) menyatakan bahwa adanya sinergi dengan pemerintah setempat dalam hal sarana dan prasarana guna memperlancar kegiatan pengembangan untuk mencapai tujuan yang diharapkan. Beraneka metode pengembangan jagung menggunakan beberapa model usaha pengembangan seperti, adanya lembaga baik dari segi sarana dan prasarana sampai pada lembaga perbankan sehingga dapat dijadikan acuan pengembangan komoditi jagung (Dewi, Tahir, Tawali, Mahendradatta, \& Korespondensi, n.d.). Selain itu, pengembangan jagung dapat memberikan hal positif sebagai penggerak pangan, industri pengolahan dan energi (Bantacut;dkk, 2015).

Penelitian ini, menggunakan pemanfaatan jagung sebagai sumber pangan yaitu mengubah jagung produksi Kab. sumenep menjadi produk yang dapat berdaya saing dan memiliki nilai tambah 
sehingga meningkatkan pendapatan masyarakat petani jagung. Pengembangan olahan jagung menjadi produk minuman yang meberikan manfaat bagi kesehatan.

Produk minuman fungsional ini bertujuan mendapatkan respon masyarakat sehingga produk dapat diterima dengan baik. Menurut (Masniah, 2013) produk olahan harus memiliki citarasa, penampilan menarik serta aman untuk dikonsumsi serta memiliki kemasan yang bagus. pada review jurnal (Tarwendah, 2017) menyimpulkan bahwa dalam mengkonsumsi produk pangan harus memperhatikan kualitasnya, bukan hanya karena brand produk tersebut. (Susiwi, 2009) uji kesukaan konsumen salah satu cara meningkatkan kualitas suatu produk sehingga dapat menghasilkan produk sesuai dengan keinginan konsumen.

Tujuan penelitian ini untuk pengembangan olahan jagung menjadi produk yang memiliki manfaat bagi kesehatan tubuh dan untuk mengetahui kesukaan konsumen terhadap minuman fungsional yaitu yogurt jagung manis.

\section{METODE}

\section{Tempat dan Waktu}

Penelitian dilaksanakan di Laboratorium Rekayasa Hasil Pertanian dan Laboratorium Uji Inderawi Fakultas Pertanian Universitas Wiraraja, dilaksanakan bulan September 2018.

\section{Alat dan Bahan}

Alat yang digunakan yaitu Pisau, Blender, wadah stenless stell, Saringan, Timbangan, Kompor, Lab, Termometer, Sendok, Beaker glass. Bahan yang digunakan adalah Jagung Manis (Zea mays saccharata), susu bubuk full cream (bahan kering $97 \%$, protein $25 \%$, laktosa $37 \%$, dan lemak 29\%), starter yoghurt (S.thermophilus, L. bulgaricus, dan L. Acidophilus : 1:1:1 ratio), Carboxy Methyl Cellulose (CMC).

\section{Prosedur}

\section{Pembuatan Susu Jagung Manis}

Pemilihan jagung manis adalah yang muda, usia panen diperkirakan 60 hari dengan biji berwarna kuning, rambut jagung berwarna putih kemerahan, tidak terlalu keras. Jagung tersebut dikukus hingga matang selama 30 menit lalu dinginkan. Kupas dan pipil biji jagung dengan pisau. Penghancuran biji jagung menjadi susu jagung dengan penambahan air sebanyak 1:1 terhadap berat jagung yang akan dihancurkan. Sesuai dengan (Rafika, 2016) perbandingan air mineral dan jagung yang memiliki organoleptik terbaik adalah 1:1 (berbanding sama). Penghancuran menggunakan blender selama 5 menit. Setelah menjadi bubur jagung manis disaring dengan kain saring menjadi sari jagung manis (susu jagung manis).

\section{Pembuatan Yogurt Jagung Manis}

Susu Jagung manis akan diolah menjadi yogurt jagung manis dengan menambahkan bahan pengemulsi $(\mathrm{cmc})$ sebanyak $0,75 \%$ dari berat bahan, dan penambahan susu bubuk full cream (10\%, $12 \%$ dan 14\%). Pasteurisasi hingga suhu 90c selama 30 menit, dan dinginkan. Setelah suhu mencapai 40 - 45c, kultur bakteri yogurt ditambahkan (inokulasi) sebanyak $10 \%$ dari berat bahan dan diaduk, setelah itu beaker glass ditutup rapat dengan aluminium foil. Fermentasi selama 24 jam untuk menjadi yogurt susu jagung. Produk yogurt jagung manis di 
simpan dalam lemari pendingin pada suhu 2 - 4c selama 24 jam lalu diuji organoleptik dengan uji kesukaan terhadap rasa, warna, aroma, dan total penerimaan panelis terhadap produk.

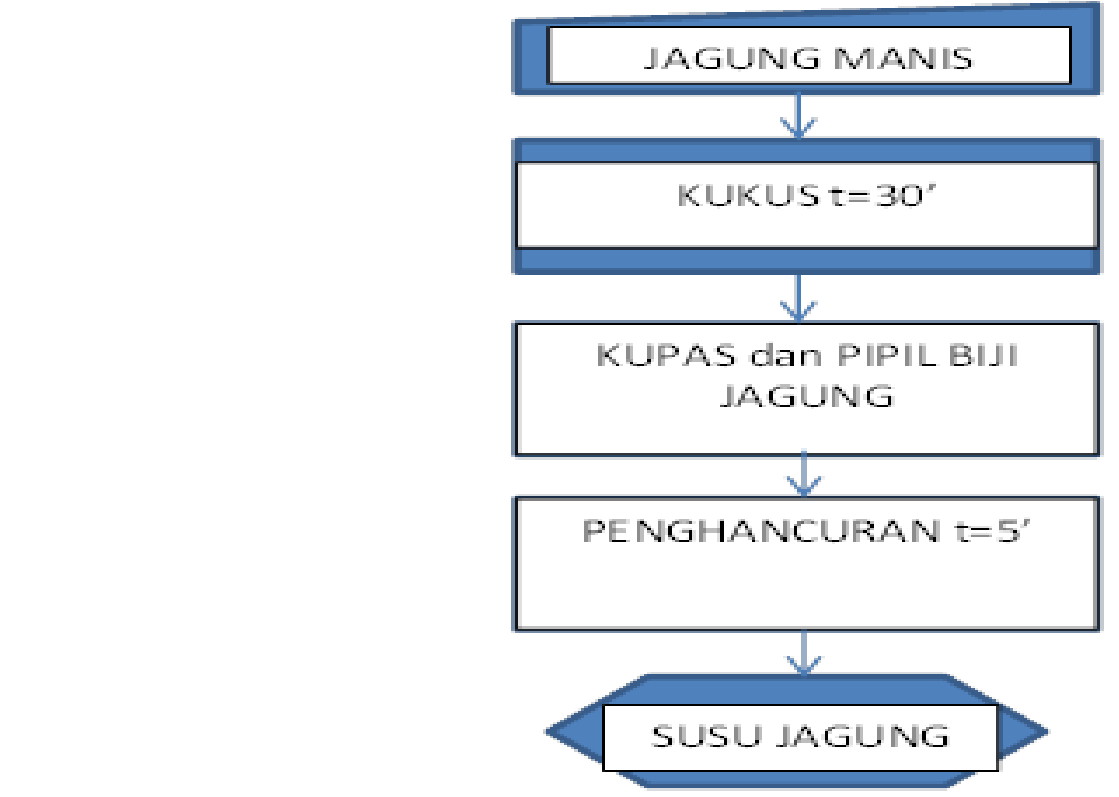

Gambar 1. Diagram Alir Proses Pembuatan Susu Jagung
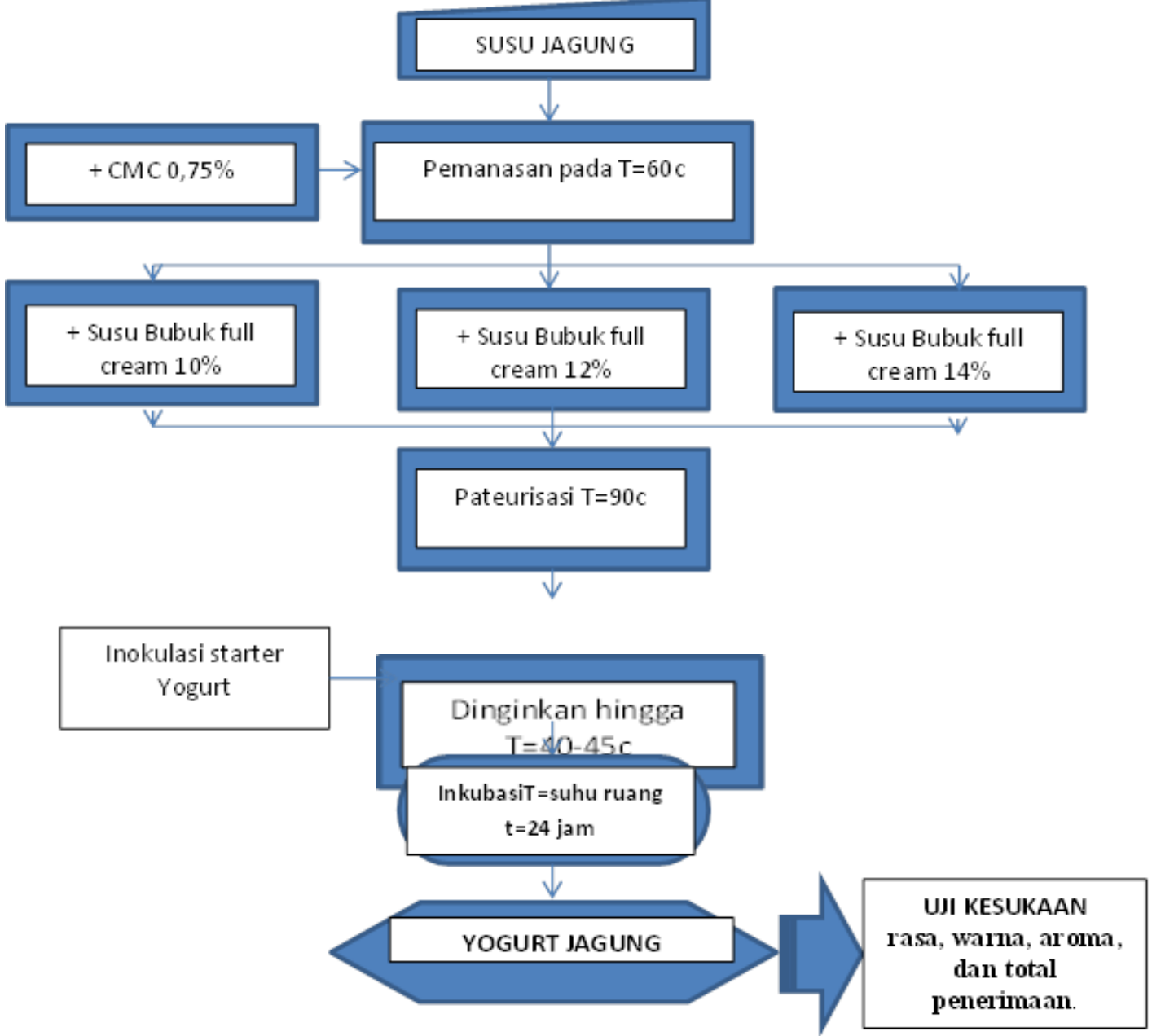


\section{Pengamatan dan Olah Data}

Pengamatan dilakukan dengan uji kesukaan konsumen yaitu dengan 6 skala hedonik yang meliputi amat sangat suka (5), sangat suka (4), suka (3), agak suka (2), netral (1) dan tidak suka (0) dengan panelis tidak terlatih sebanyak 80 orang.

\section{HASIL DAN PEMBAHASAN}

Prospek pengembangan olahan jagung menjadi produk yang berkualitas sehingga memberikan manfaat bagi manusia. Pangan fungsional merupakan salah satu cara menjadikan jagung menjadi minuman kesehatan (yogurt). Menurut (Suter, 2013) minuman fungsional dapat mencegah penyakit degeratif sehingga di prediksi dapat meningkatkan permintaan pangan fungsional. (Rina Agustina;, 2018) pengembangan produk olahan sebagai pangan fungsional harapannya dapat memenuhi tujuan dalam pemenuhan gizi masyarakat dan menurunkan resiko penyakit akibat pangan di masyarakat.

\section{Warna}

Mutu pangan tergantung pada beberapa faktor seperti citarasa, warna, tekstur dan nilai gizinya. Secara visual, warna sangat menentukan dan dapat digunakan sebagai indikator pada mutu pangan (Winarno, 1992).

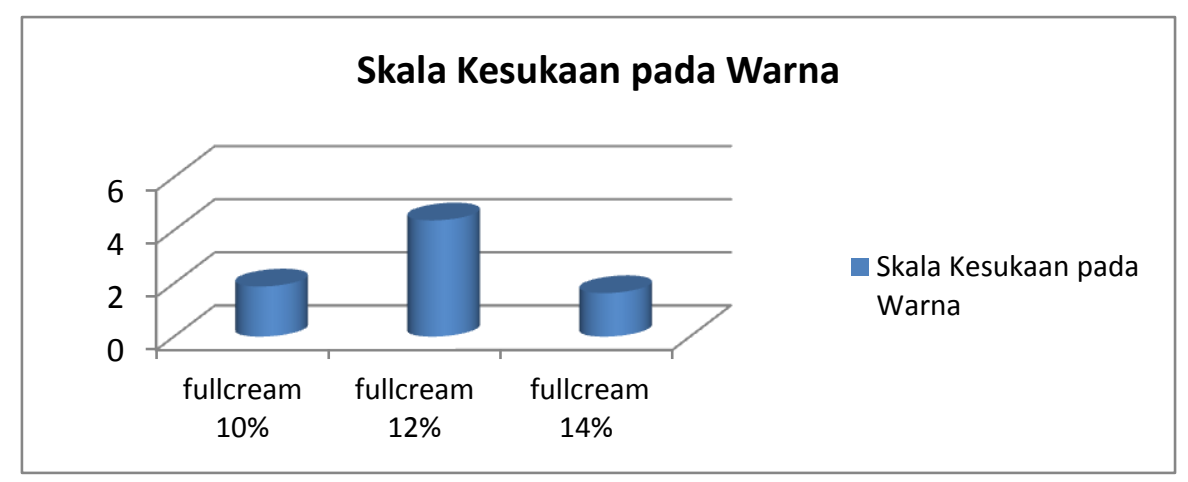

Gambar 1. Grafik skala kesukaan konsumen terhadap warna yogurt jagung

Berdasarkan gambar 1 diketahui skala kesukaan pada warna lebih menyukai dengan penambahan fullcream $12 \%$, karena berwarna kuning sperti warna jagung karena jagung manis mengandung $\beta$-karoten. (Aak, 1993) menyebutkan karena warna produk minuman fermentasi ekstrak jagung manis memiliki warna yang khas yang berasal dari bahan baku jagung manis yaitu kuning karena banyak mengandung pigmen karoten.

\section{Tekstur}

Tekstur yang disukai oleh konsumen yaitu pada perlakuan penambahan susu fullcream sebesar $12 \%$. Hal ini diduga dengan penambahan $12 \%$ menghasilkan yogurt jagung yang kental dan 
sangat kental serta homogen, serta teksturnya lembut. Berdasarkan hasil tersebut, sudah sesuai dengan Standart pembuatan minuman fermentasi ekstrak jagung manis menghasilkan penampakan terbaik karena memenuhi persyaratan yoghurt (SNI, 1992).

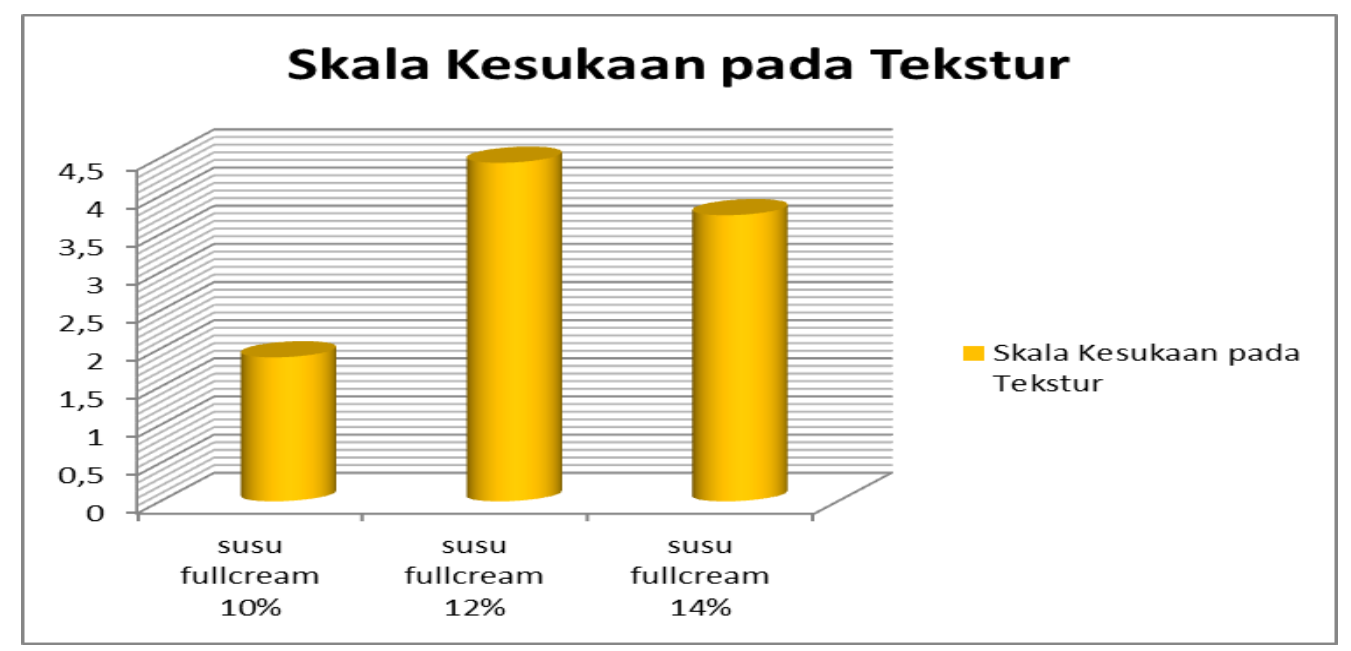

Gambar 2. Grafik skala kesukaan konsumen terhadap tekstur yogurt jagung

Aroma

Aroma yang dihasilkan oleh yogurt jagung pada penambahan fullcream sebanyak $12 \%$ karena aromanya sangat khas jagung. (Putri*, 2015) mengatakan bahwa aroma merupakan salah satu penentu kualitas makanan supaya dapat diterima konsumen. Seperti pada gambar 3 dibawah ini.

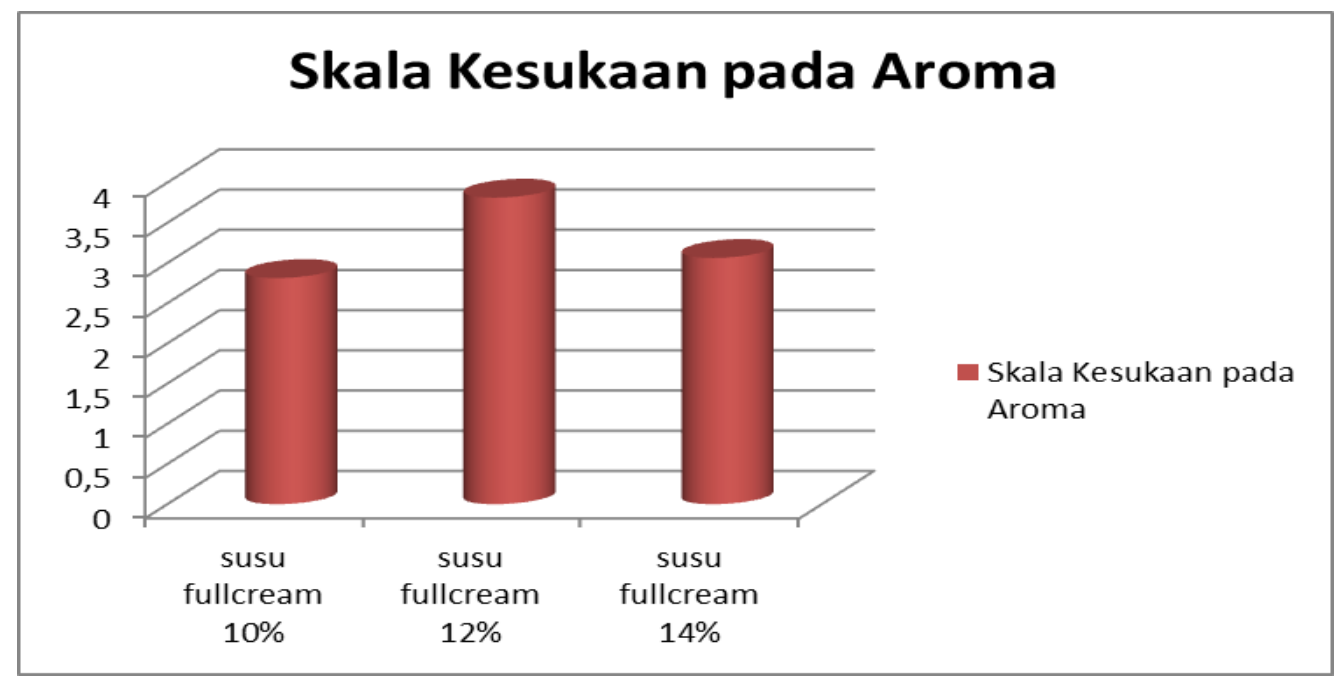

Gambar 3. Grafik skala kesukaan konsumen terhadap Aroma yogurt jagung

\section{Rasa}

Rasa merupakan sensasi yang terbentuk dari hasil perpaduan komposisi bahan pada suatu produk makanan yang ditangkap oleh indera pengecap (Hartatie, 2011). Penambahan fullcream sebesar $14 \%$ menghasilkan rasa khas yogurt dengan kekentalan yang disukai konsumen. Hasil uji kesukaan panelis terhadap yogurt dengan berbgai perlakuan sebagaimana disajikan pda Gambar 4. 


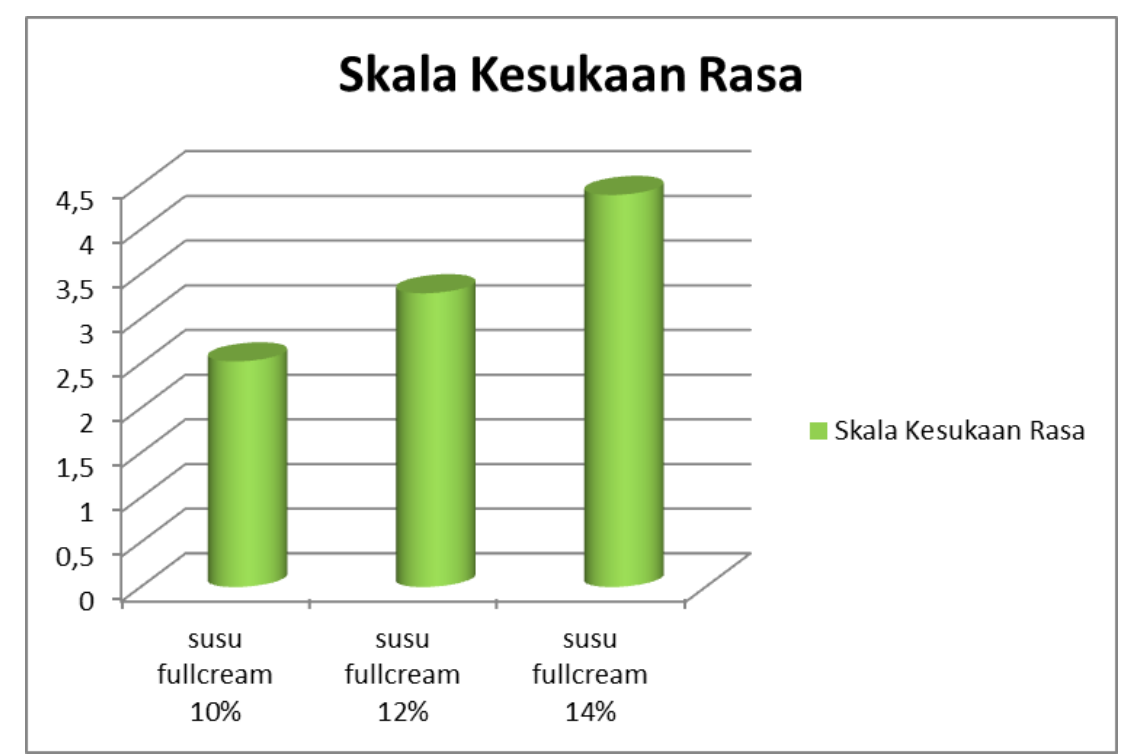

Gambar 4. Grafik skala kesukaan konsumen terhadap Rasa yogurt jagung

\section{KESIMPULAN}

1. Pengembangan produk olahan jagung dengan mengolah menjadi pangan fungsional yang dapat memberikan pengarahan pada masyarakat terhadap penurunan resiko penyakit dalam pemenuhan gizi seimbang.

2. Berdasarkan hasil uji kesukaan konsumen pada penelitian pengembangan produk olahan jagung (yogurt) dari segi rasa, konsumen lebih menyukai penambahan fullcream $14 \%$ karena rasa dihasilkan sangat khas jagung dan ada rasa asam yang menandakan adanya perlakuan fermentasi. Sedangkan pada warna, tekstur dan aroma yang dihasilkan konsumen lebih memilih pada konsentrasi $12 \%$.

\section{DAFTAR PUSTAKA}

Aak. 1993. Teknik Bercocok Tanam Jagung. Canisius. Yogyakarta

Aldillah, R. (2017). STRATEGI PENGEMBANGAN AGRIBISNIS JAGUNG DI INDONESIA National Maize Agribusiness Development Strategy. Analisis Kebijakan Pertanian, 15(1), 43-66.

Amelia, D. (n.d.). YOGHURT SUSU
JAGUNG MANIS KACANG HIJAU SEBAGAI STRATEGI INOVASI PRODUK ALTERNATIF PANGAN FUNGSIONAL. Jurnal Teknik Industri, 172-183.

Anggono;dkk. (2017). STUDI PENGARUH PENAMBAHAN SUSU KEDELAI (Glycine max L) DAN SUSU JAGUNG MANIS (Zea mays L Saccharata) TERHADAP MUTU DAN ORGANOLEPTIK ES KRIM. Jurnal Teknologi Pangan, 8(1), 1-8.

Bantacut;dkk. (2015). Pengembangan Jagung untuk Ketahanan Pangan, Industri dan Ekonomi. PANGAN, 135-148.

Dewi, N., Tahir, M. M., Tawali, A. B., Mahendradatta, M., \& Korespondensi, A. (n.d.). DI KABUPATEN TAKALAR THE DEVELOPMENT OF INTEGRATED CORN BUSINESS MODEL IN TAKALAR REGENCY Nirmala Dewi, STP Fakultas Pertanian Universitas Hasanuddin.

Masniah, S. (2013). PEMANFAATAN JAGUNG DALAM PEMBUATAN ANEKA MACAM OLAHAN. Seminar Nasional Serealia, 537-542.

Putri*, D. (2015). PENGARUH RASIO SUSU FULL CREAM DENGAN JAGUNG MANIS (Zea mays saccharata) TERHADAP NILAI GIZI, SIFAT FISIK 
DAN ORGANOLEPTIK ES KRIM. Pro Food (Jurnal Ilmu Dan Teknologi Pangan), 1(1), 15-23.

Rafika, M. (2016). KARAKTERISTIK FISIK DAN ORGANOLEPTIK YOGHURT SUSU JAGUNG DENGAN PENAMBAHAN BESI DAN VITAMIN A, 1-36.

Rina Agustina; (2018). Kajian Manfaat Pangan Fungsional Setelah Terpenuhinya Gizi Seimbang. Pra-Widyakarya Nasional Pangan Dan Gizi Hotel Kartika Chandra, 22-23 Mei 2018, 22-23.

Susiwi. (2009). Penilaian organoleptik. UNIVERSITAS PENDIDIKAN INDONESIA, (Ki 531).

Suter. (2013). PANGAN FUNGSIONAL DAN PROSPEK

Winarno (1992). KIMIA PANGAN DAN GIZI, Cetakan ke-6, Penerbit PT. Gramedia Pustaka Utama.
PENGEMBANGANNYA. Makalah Disajikan Pada Seminar Sehari Dengan Tema "Pentingnya Makanan Alamiah (Natural Food) Untuk Kesehatan Jangka Panjang" Yang Diselenggarakan Oleh Ikatan Keluarga Mahasiswa (IKM) Jurusan Gizi Politeknik Kesehatan Denpasar, Tgl. 18 Agustus 2013 Di Denp, 1-17.

Tarwendah, I. P. (2017). JURNAL REVIEW : STUDI KOMPARASI ATRIBUT SENSORIS DAN KESADARAN MEREK PRODUK PANGAN Comparative Study of Sensory Attributes and Brand Awareness in Food Product : A Review. Jurnal Pangan Dan Agroindustri, 5(2), 66-73. 